\title{
PROGRAM PERANCANG KELUARGA DALAM PERKHIDMATAN KESIHATAN AWAM DI SEMENANJUNG MALAYSIA, 1957-1975
}

\author{
Wan Mohd Rahimi Bin Rahim \\ Ahmad Kamal Ariffin Mohd Rus
}

\begin{abstract}
This article discusses the family planning programme in the public health service between 1957 and 1975 in Peninsular Malaysia. The Family Planning Programme began in 1966 to regulate the annual population growth rate which was disproportionate to economic development. The government felt that the unchecked population growth might affect the population health status, especially causing deaths due to disease complications. This method of family planning, other than addressing the medical problem, aimed from an economic standpoint to balance population growth and national development. This study analyse the extent of the efficacy of the family planning programme in addressing the problem of unchecked population growth, and ensuring the improvement of health level and economic development. The findings show that the family planning programme succeeded in reducing population growth after its launch. Through its programmes, at the end of 1970, statistics show that around 78,400 birth were prevented, and this meant the population at the time was aware of family planning education. In addition, maternal and child mortality rates also dwindled. Therefore, it can be argued that this policy by the government was effective in controlling population growth in the context of health control and ensured the prevention of the negative impact of unchecked birth rates.
\end{abstract}

\section{Pengenalan}

Program perancang keluarga merupakan salah satu program yang diperkenalkan oleh kerajaan bagi mengawal pertumbuhan penduduk 
di negara ini. Selepas merdeka, negara mula merancakkan agenda ke arah pembangunan negara. Dalam tempoh ini, kerajaan melihat kadar pertumbuhan penduduk negara tidak terkawal terutama di Semenanjung Malaysia dan memberi kesan yang negatif terhadap pembangunan negara. Faktor demografi dan juga faktor kesihatan telah dikenal pasti sebagai dua aspek utama yang mempengaruhi pengenalan program perancang keluarga. Berdasarkan kedua-dua faktor ini, program perancang keluarga telah dijadikan sebagai akta rasmi negara bermula dalam tempoh Rancangan Malaysia Pertama.

Perancang keluarga ditakrifkan sebagai satu aktiviti merancang masa yang sesuai untuk mengandung dengan menggunakan kaedah bagi menjarakkan kandungan dan merancang saiz sesebuah keluarga yang diingini. Sekitar tahun 1960-an, program perancang keluarga telah dilancarkan di kebanyakan negara Selatan dan Timur Asia termasuk juga di India, Pakistan dan Sri Lanka. Langkah kawalan penduduk ini dilaksanakan bagi mengatasi masalah kepadatan penduduk dan ekonomi di negara-negara tersebut. Program perancang keluarga di peringkat antarabangsa kebanyakannya bekerjasama dengan pertubuhan-pertubuhan perancang keluarga antarabangsa dan juga WHO yang membantu dari segi kepakaran dan juga peralatan.

\section{Sejarah Awal Program Perancang Keluarga Di Malaysia}

Pergerakan aktiviti perancang keluarga telah mula berkembang dengan pesat pada pertengahan tahun 1960-an sehingga pertengahan tahun 1990-an. Individu pertama yang menggerakkan program kawalan kelahiran di peringkat antarabangsa ialah Margeret Sanger. ${ }^{1}$ Beliau bekerja sebagai jururawat di sekitar tahun 1920-an dan melihat ramai golongan ibu-ibu yang nekad melakukan pengguguran kandungan. Kesan daripada peristiwa tersebut menyebabkan beliau terlibat aktif dalam bidang perancang keluarga dan berjaya menerbitkan buku bertajuk "The Women Rebel". ${ }^{2}$ Beliau akhirnya berjaya membuka klinik perancang keluarga pertama di Amerika Syarikat. Selepas itu, usaha ini diteruskan oleh perintis lain secara aktif bermula pada tahun pertama abad ke-20. Jika ditelusuri dari segi sejarah di Malaysia, program perancang keluarga mula diperkenalkan di peringkat negeri. Sekitar tahun 1930-an, perintis utama yang mula menggerakkan program ini adalah Dr A.E Doraisamy. ${ }^{3}$ Beliau merupakan seorang pakar obstetrik hospital kerajaan di Kuala Lumpur. Beliau sangat bimbang dengan kadar kematian bayi dan ibu bersalin yang begitu tinggi pada ketika itu. Beliau bertindak untuk menasihati pasangan suami isteri mengenai aktiviti perancang keluarga. Dr A. E Doraisamy menganggap tindakan beliau adalah satu langkah kemanusiaan bagi mengelakkan risiko 
kematian bayi dan ibu yang semakin meningkat. Pada tahun 1938, Dr A.E Doraisamy membentuk jawatankuasa sukarela bagi melaksanakan aktiviti perancang keluarga. Ahli-ahli terdiri daripada sepuluh orang ahli iaitu lima orang Eropah, dua wanita berbangsa Cina dan tiga orang doktor (termasuk beliau). ${ }^{4}$ Komuniti yang ditubuhkan ini semakin aktif di sekitar Kuala Lumpur sehingga Jepun menduduki Tanah Melayu.

Selepas Perang Dunia Kedua berakhir, Dr A. E Doraisamy menjawat jawatan sebagai Ahli Majlis Pembandaran di Kuala Lumpur. Dr A.E Doraisamy bersama beberapa orang doktor dan jururawat yang lain secara peribadi telah terlibat sebagai individu yang bertanggungjawab dalam perkhidmatan perancangan keluarga. Sehingga Julai 1953, usaha yang dilaksanakan oleh individu ini akhirnya berjaya menubuhkan Persatuan Perancang Keluarga Negeri pertama di Kuala Lumpur dan di negeri Selangor. ${ }^{5}$ Kejayaan ini membawa kepada idea penubuhan Persatuan Perancang Keluarga di negeri-negeri lain iaitu di Johor pada tahun 1954, Perak pada tahun 1956 dan Melaka pada tahun 1957. Pada tahun 1958, keempat-empat Persatuan Perancang Keluarga Negeri ini telah bergabung bagi membentuk Federation of Family Planning Associations (FFPA) atau dalam bahasa Melayu iaitu Persekutuan Persatuan-Persatuan Perancang Keluarga. ${ }^{6}$ Pada tahun 1962, FFPA telah berjaya menggalakkan lebih banyak pembentukan Persatuan Perancang Keluarga Negeri yang pada awalnya difokuskan di negeri-negeri di sebelah Semenanjung Malaysia sahaja. ${ }^{7}$

Dalam usaha untuk meningkatkan lagi peranan program perancang keluarga, FFPA telah menyertai kegiatan yang bertaraf antarabangsa dengan menganggotai International Planned Parenthood Federation yang berpengalaman luas di peringkat antarabangsa. ${ }^{8}$ Pada peringkat awal jelas menampakkan bahawa wujudnya golongan yang peka terhadap masalah yang timbul akibat pertumbuhan penduduk yang mendadak tanpa kawalan. Aktiviti ini diteruskan sehinggalah program perancang keluarga mula mendapat perhatian kerajaan dan menjadikan program perancang keluarga sebagai salah satu dasar utama kerajaan pada tahun 1966.

Pada tahun 1962, Tun Abdul Razak selaku Timbalan Perdana Menteri telah melihat program perancang keluarga sebagai salah satu strategi yang berupaya untuk meningkatkan taraf hidup penduduk di Malaysia. ${ }^{9}$ Tun Abdul Razak percaya bahawa setiap penduduk yang terdiri daripada pelbagai disiplin ilmu akan melihat usaha ini sebagai satu usaha yang boleh memberi kesan yang baik kepada kepelbagaian sektor di negara ini terutama dalam bidang kesihatan dan ekonomi. Menurut ahli demografi, program perancang keluarga adalah satu keperluan penting bagi menggalakkan pertumbuhan ekonomi negara yang sedang membangun. Secara peribadi, Tun Abdul Razak lebih 
gemar melihat perancang keluarga ini dari konsep penggunaan istilah 'keluarga berencana' berbanding 'perancang keluarga'. ${ }^{10}$ Setelah program ini dijadikan sebagai salah satu dasar kerajaan, wujud pelbagai tafsiran positif mengenai aktiviti perancang keluarga di negara ini namun, ada juga sesetengah pihak yang melihat bahawa aktiviti ini dianggap berdosa. ${ }^{11}$

\section{Faktor-Faktor Pengenalan Program Perancang Keluarga di Semenanjung Malaysia}

Selepas Merdeka, Persekutuan Tanah Melayu mula melaksanakan agenda pembangunan melalui program pembangunan yang bersifat jangka panjang. Rancangan Malaya Pertama 1957-1960 dan Rancangan Malaya Kedua 1960-1965 dilihat sebagai satu perancangan awal kerajaan dalam merangka pembangunan negara selepas merdeka. Dalam tempoh ini, kemajuan dari segi ekonomi dan sosial masih lagi lemah kerana Persekutuan Tanah Melayu berada dalam proses untuk berdiri sebagai sebuah kerajaan yang merdeka. Kemajuan besar telah dibuat di bawah rancangan lima tahun pertama. Dalam kajian semula rancangan di bawah Pelan Lima Tahun Kedua 1961-1965, menunjukkan pengukuhan telah dibuat hampir semua sektor dalam sasaran rancangan lima tahun ini. Walaupun pengukuhan telah dibuat, pembangunan di Persekutuan Tanah Melayu telah mula dibayangi oleh dua faktor yang membimbangkan iaitu kejatuhan harga getah dan pertumbuhan pesat penduduk Tanah Melayu yang tidak terkawal. ${ }^{12}$ Dalam menghadapi situasi sebegini, kerajaan mula mengambil langkah bagi mengawal kadar pertumbuhan penduduk.

Kerajaan melihat faktor demografi tanpa kawalan memberi kesan terhadap kemajuan ekonomi negara. Semasa pendudukan British, pertumbuhan penduduk tahunan sentiasa meningkat tidak lebih dari 2.4 peratus setahun sejak tahun 1911. Pada tahun 1952, pertumbuhan penduduk di Persekutuan Tanah Melayu telah mencapai tahap tiga peratus setahun. Walaupun peratus pertumbuhan pada tahun yang dinyatakan dilihat kecil, situasi itu dilihat tidak selaras dengan kadar pertumbuhan ekonomi. ${ }^{13}$ Dalam bancian yang dilakukan pada tahun 1957 menunjukkan jumlah penduduk pada masa itu adalah seramai 6.28 juta orang. ${ }^{14}$ Jika kadar pertambahan penduduk pada tahap 3 peratus setahun diteruskan tanpa kawalan, penduduk Persekutuan Tanah Melayu akan bertambah sehingga 12.56 juta orang sebelum tahun 1980. Secara teori yang dapat dianggarkan, kemungkinan pertumbuhan penduduk akan mencapai peningkatan sebanyak empat kali ganda daripada jumlah penduduk pada tahun $1957 .{ }^{15}$ Jadual 1 memperincikan mengenai perkembangan penduduk dari tahun 1957 hingga 1961. 
Jadual 1: Jumlah Pertambahan Penduduk Mengikut Kaum Dari Tahun 1957-1961 di Persekutuan Tanah Melayu

\begin{tabular}{|c|c|c|c|c|c|}
\hline \multirow[b]{2}{*}{ Kaum } & \multicolumn{5}{|c|}{ TAHUN } \\
\hline & 1957 & 1958 & 1959 & 1960 & 1961 \\
\hline Semua Kaum & 6278673 & 6515385 & 6697827 & 6909009 & 7136804 \\
\hline$\%$ Pertambahan & & 3.77 & 2.8 & 3.15 & 3.3 \\
\hline Melayu & 3126706 & 3241766 & 3345491 & 3460956 & 3576889 \\
\hline$\%$ Pertambahan & & 3.68 & 3.2 & 3.45 & 3.35 \\
\hline Cina & 2332936 & 2415378 & 2480049 & 2552276 & 2633516 \\
\hline$\%$ Pertambahan & & 3.53 & 2.68 & 2.91 & 3.18 \\
\hline India & 706907 & 737489 & 751491 & 772880 & 796880 \\
\hline$\%$ Pertambahan & & 4.33 & 1.9 & 2.85 & 3.11 \\
\hline Lain-lain & 112214 & 120752 & 120796 & 122897 & 129519 \\
\hline$\%$ Pertambahan & & 7.61 & 0.003 & 1.74 & 5.39 \\
\hline
\end{tabular}

Sumber: Report no.14, Calculated from 1957 population Census of the Federation of Malaya, Fail Jabatan Perdana Menteri.

Peningkatan jumlah penduduk jelas dilihat telah memberi kesan kepada ekonomi negara. Kerajaan melihat perkembangan penduduk tanpa kawalan memberi kesan yang negatif terhadap ekonomi bermula tahun 1961-1963. ${ }^{16}$ Pada tempoh tersebut, jumlah penduduk telah meningkat ke tahap 3.2 peratus setahun dan produk per kapita negara menurun sebanyak empat peratus dan tahapnya hampir sama pada tahun 1962. Masalah ekonomi ini bermula pada tahun 1961 di mana pengeluaran fizikal negara mencatatkan peningkatan secara purata sebanyak 4.5 peratus setahun. Pada tahun 1962 pula, peningkatan hanya sebanyak satu peratus sahaja dari tahun sebelumya. Hal ini disebabkan peningkatan populasi penduduk berlaku secara mendadak. ${ }^{17}$ Pendapatan per kapita negara pula telah menurun sedikit daripada tahap tertinggi yang pernah dicapai pada tahun 1960. Pada tahun 1962, dianggarkan jumlah penduduk telah meningkat 6.8 peratus dan dijangkakan meningkat lagi sehingga 8.5 peratus pada pertengahan tahun 1963. Pada akhir tahun 1960 hingga akhir tahun 1962, nilai keluaran negara kasar pada harga pasaran semasa meningkat dari angka indeks ${ }^{18} 100$ kepada 102.1. Disebabkan peningkatan penduduk, nilai per kapita pada harga pasaran semasa merosot pada kadar 100 kepada 95.8. Pakar-pakar ekonomi pada masa itu berpendapat, hal ini disebabkan faktor pertambahan penduduk yang terus meningkat. ${ }^{19}$ Berdasarkan statistik yang dinyatakan, pertumbuhan penduduk tanpa 
kawalan telah mengakibatkan kedudukan ekonomi pada masa itu terjejas. Sekiranya kerajaan tidak mengambil inisiatif dalam mengawal kadar pertumbuhan penduduk, kerajaan akan berhadapan masalah dalam memacu perkembangan ekonomi ke tahap yang lebih baik.

Faktor lain yang turut mempengaruhi kerajaan untuk merangka program perancang keluarga ialah faktor kesihatan. Kadar kematian bayi dan juga kematian ibu mengandung masih tinggi terutama di kawasan luar bandar. Sebilangan besar kes kematian ini melibatkan orang Melayu. ${ }^{20}$ Kes kematian bayi dan ibu bersalin ini disebabkan oleh kekerapan pasangan melahirkan anak secara tidak terancang. Kekerapan kelahiran akan menyebabkan golongan ibu tidak dapat memberikan perhatian kepada kesihatannya dan juga kesihatan anak-anak mereka yang ramai. ${ }^{21}$ Pada tahun 1957-1970, perkhidmatan kesihatan awam di luar bandar terutama di kawasan Pantai Timur masih lagi kurang memuaskan. Sehingga tahun 1970, purata perkhidmatan kesihatan awam meliputi sebanyak 17,000 penduduk di Perlis, 33,000 penduduk di Kedah, 14,000 penduduk di Pahang, 18,500 penduduk di Terengganu, dan 24,000 penduduk di Kelantan yang dinisbahkan dengan satu pusat kesihatan. ${ }^{22}$

Berdasarkan jumlah yang dinyatakan, negeri-negeri ini telah mencatatkan jumlah kematian bayi dan ibu bersalin yang amat tinggi. Jika dilihat pada tahun 1957, kadar kematian kanak kanak Melayu pada waktu itu adalah sebanyak 2.14 kali ganda jika dibandingkan dengan kematian kanak-kanak Cina. Pada tahun 1970 pula kadar kematian bagi kanak-kanak Melayu telah meningkat kepada 2.77 kali ganda. ${ }^{23}$ Kadar kematian ibu bersalin di Kelantan semakin meningkat dari 0.8 peratus dalam tahun 1970 kepada 1.18 peratus pada tahun $1971 .{ }^{24}$ Encik Khir Johari dalam ucapanya pada 1971 (Menteri Perdagangan dan Perusahaan dan merangkap Pengerusi Lembaga Perancang Keluarga Kebangsaan) menyatakan bahawa:

Perancang keluarga bukan untuk menjarangkan anak, tetapi untuk melihat ibu-ibu sihat yang dapat melayan setiap keluarganya ...di Sg Petani, angka kelahiran bayi sangat tinggi jika dibandingkan dengan tempat lain, tetapi peningkatan penduduk di kawasan itu tidak begitu seimbang dengan peningkatan pendapatan penduduk di kawasan itu. ...Setiap 1000 orang bayi yang dilahirkan, sebanyak 96/1000 telah mati semasa dilahirkan dan angka ini amat tinggi yang melibatkan orang Melayu yang tinggal di luar bandar. Masalah penganguran yang dihadapi oleh negara dapat dikawal sekiranya pertumbuhan penduduk dapat dikawal. ${ }^{25}$

Sekiranya kadar pertumbuhan penduduk tidak dipandang dengan serius oleh kerajaan, masalah kematian bayi dan ibu bersalin akan terus 
menghantui penduduk terutama pasangan yang berkeluarga. Oleh itu, faktor ini diketengahkan dan dijadikan alasan utama oleh kerajaan bagi mengalakkan pasangan untuk merancang keluarga.

\title{
Struktur Pelaksanaan Program Perancang Keluarga
}

Program perancang keluarga adalah keperluan utama dalam memastikan pertumbuhan penduduk dapat dikawal bagi tujuan perkembangan ekonomi dan kesihatan negara. Pada peringkat permulaan, kabinet telah mengambil keputusan untuk menerima Program Perancang Keluarga sebagai satu polisi rasmi dan program ini dimasukkan ke dalam Rancangan Malaysia Pertama 1966-1970. ${ }^{26}$

\begin{abstract}
Ranchangan Peranchang Keluarga yang dimulakan dalam tempoh Ranchangan Malaysia Pertama telah membuat kemajuan yang memuaskan. Ranchangan ini menjangkakan iaitu pada tahun 1985 kadar tambahan penduduk tahunan akan dikurangkan dari kadar sekarang sebanyak 3\% menjadi 2\%. Ranchangan Kerajaan adalah ditumpukan kepada Malaysia Barat. Malaysia Timor telah mendapat perkhidmatan dari Persatuan Peranchang Keluarga dan lain-lain pertubuhan sukarela. ${ }^{27}$
\end{abstract}

Kerajaan telah melihat bagaimana negara-negara luar seperti Turki, Mesir, dan Taiwan telah menjadikan program perancang keluarga sebagai salah satu keutamaan tertinggi dalam pelaksanaan dasar negara tersebut. Dalam melaksanakan program perancang keluarga dengan berkesan, agensi yang melaksanakan program ini haruslah mempunyai kuasa autonomi atau separa autonomi supaya tidak terbeban dengan pelbagai karenah biokrasi. ${ }^{28}$ Bagi menjadikan program perancang keluarga ini lebih efektif, kerajaan tidak seharusnya terlalu bergantung kepada pertubuhan sukarela yang sedia ada. Oleh itu, kerajaan seharusnya mewujudkan sebuah badan eksklusif melalui Akta Parlimen bagi mendapatkan kuasa autonomi dalam melaksanakan program perancang keluarga di negara ini. ${ }^{29}$

Pada tahun 1965, kerajaan telah meneliti kertas cadangan yang dikeluarkan Persekutuan Persatuan-Persatuan Perancang Keluarga Malaysia $^{30}$ dan menerima kertas cadangan ini untuk dilaksanakan. Setelah dipersetujui, tanggungjawab untuk membentuk polisi perlu dilaksanakan. Sebuah jawatankuasa kecil dalam kabinet dibentuk untuk membuat cadangan mengenai cara-cara untuk memperluas rancangan ini kepada penduduk tempatan. Bagi melaksanakan program ini, langkah yang bersepadu adalah melalui kaedah kempen-kempen dan juga pendidikan bagi memperluas program ini di Malaysia. ${ }^{31}$ Pada peringkat awal, ahli jawatankuasa Program Perancang Keluarga telah 
mengemukakan beberapa cadangan iaitu kementerian manakah yang harus diberi tanggungjawab bagi menggubal dasar dan melaksanakan program ini di bawah Rancangan Malaysia Pertama. Pembentukan program perancang keluarga merupakan satu program kerajaan yang baru dan setiap kementerian tidak mempunyai pengalaman yang jelas mengenai program ini. ${ }^{32}$

Dalam kertas cadangan yang dibuat oleh Persekutuan PersatuanPersatuan Perancang Keluarga Malaysia telah mencadangkan agar Kementerian Kesihatan Malaysia menjadi peneraju utama program ini. Ini disebabkan pengalaman yang dimiliki oleh Kementerian Kesihatan Malaysia (KKM) dalam mengawal penyakit malaria dan juga tuberculosis. Kawalan penyakit ini dijalankan dengan giat oleh KKM dalam mengawal penularan wabak penyakit dan berjaya menyedarkan penduduk mengenai program kawalan dan juga memperkenalkan kaedah rawatan yang terbaik. Pengalaman yang dimiliki oleh KKM dijadikan panduan dan merupakan keputusan yang tepat dengan meletakkan program perancang keluarga di bawah KKM. ${ }^{33} \mathrm{KKM}$ telah meletakkan tanggungjawab perancang keluarga di bawah Perkhidmatan Kesihatan Luar Bandar sejak 1971. ${ }^{34}$

Walaupun program ini bersifat kesihatan, namun penglibatan KKM dalam program ini tidak meliputi sepenuhnya. Bagi menggalakkan penglibatan penduduk dalam program ini, hal yang berkaitan dengan pendidikan, pembangunan sosial, pembangunan ekonomi, ciri-ciri kaum turut menjadi elemen penting. Penglibatan kementerian lain juga turut diperlukan bagi mengatasi keterbatasan yang dimiliki oleh KKM. ${ }^{35}$ Jemaah Menteri dalam mesyuarat pada 30 September 1965 telah mempersetujui satu laporan daripada Jawatankuasa Kerja Pegawai dan juga saranan daripada satu Jawatankuasa Kecil Jemaah Menteri mengenai undang-undang untuk menubuhkan sebuah badan yang mempunyai kuasa autonomi dan saranan ini akan dibawa ke mesyuarat Parlimen yang bersidang dari 21-26 Mac 1966. ${ }^{36}$

Peraturan kerja dirangka bagi tujuan perlaksanaan tugas dalam badan yang baharu dibentuk ini. Oleh itu, satu sekretariat di bahagian perancang ekonomi, Jabatan Perdana Menteri akan menguruskan peraturan ini. En Mohd Khir Johari pula telah diberi kepercayaan oleh Jemaah Menteri bagi mengetuai segala aktiviti yang melibatkan perancang keluarga di negara ini di bawah kendalian sebuah lembaga yang mempunyai kuasa autonomi iaitu Lembaga Perancang Keluarga Negara. ${ }^{37}$ Jawatan Ketua Penolong Setiausaha telah diperkenalkan bagi membantu kerja-kerja pengarah. Pengarah yang dilantik ini perlu menjalinkan kerjasama dengan Penasihat Perancang Keluarga yang berada di setiap negeri di Semenanjung Malaysia. ${ }^{38}$ LPKN telah 
memulakan perkhidmatanya melalui kerjasama dengan Kementerian Kesihatan Malaysia dalam memperluas perkhidmatan ke klinik di bandar-bandar, di Hospital Umum, Hospital Bersalin, Hospital Daerah, Hospital Universiti, dan pusat-pusat kesihatan ibu dan kanak-kanak. Perkhidmatan ini dilaksanakan secara berperingkat bermula dari bandar ke kawasan luar bandar. ${ }^{39}$

Usaha Kerajaan dalam memperkenalkan program perancang keluarga di negara ini tidak bermaksud untuk menghalang kaum ibu dari terus melahirkan anak. Hal ini disebabkan ibu bapa bebas untuk menentukan bilangan anak mereka dan tiada satu pun akta di negara ini yang menghalang perkembangan penduduk. ${ }^{40}$ Kerajaan mengambil satu inisiatif iaitu hanya bertindak untuk memujuk golongan ibu bapa bagi mengetahui dan mengambil berat mengenai ancamanancaman penyakit yang akan menimpa kaum ibu jika mereka enggan menjarangkan kelahiran anak. Sekiranya pihak ibu bapa memberi sambutan yang baik dari program perancang keluarga yang diwujudkan oleh kerajaan, keberkesanan bukan sahaja dapat dinikmati daripada aspek kesihatan, malah peningkatan taraf hidup dapat dicapai pada masa akan datang.

\section{Pelaksanaan Program Perancang Keluarga}

Pada peringkat awal pengenalan perancang keluarga di Malaysia, pelbagai isu dan persoalan yang timbul dan dikemukakan oleh ahli parlimen untuk mendapat gambaran yang jelas mengenai dasar kerajaan yang mahu mengawal pertumbuhan penduduk di Malaysia. ${ }^{41}$ Isu ini selalu dibahaskan di Dewan Rakyat kerana perancang keluarga banyak menyentuh isu sensitiviti agama terutama agama Islam..$^{42}$ Kebanyakan ahli Parlimen terutama dalam kalangan parti PAS bangkit menyatakan bantahan dan menganggap isu ini dilihat seolah-olah ingin melawan qada' dan qadar Allah S.W.T. ${ }^{43}$ Sebagai contoh, pada 17 0ktober 1967, Tuan Hj Abu Bakar Bin Hamzah mengajukan soalan kepada Perdana Menteri mengenai perancangan keluarga yang dilihat sebagai satu rancangan kebangsaan yang ada kaitannya dengan hukum syara' Islam. ${ }^{44}$ Beliau mempersoalkan sama ada kerajaan akan menubuhkan sebuah jawatankuasa yang terdiri dari ahli yang beragama Islam yang bertindak dalam memantau aktiviti yang berkaitan dengan program perancang keluarga. Beliau berpendapat, segala hal yang berkaitan dengan hukum syara' ini haruslah diperhalusi hukumnya agar tidak bercanggah dengan agama Islam dan tidak memudaratkan penduduk. ${ }^{45}$ Berhubung dengan persoalan yang ditimbulkan, Perdana Menteri Tun Abdul Razak menyatakan "...adalah tidak perlu untuk menubuhkan jawatankuasa bagi maksud tersebut oleh kerana perancangan keluarga 
telah dijalankan dalam negara Islam lain seperti Pakistan, Republik Arab Bersatu, Turki dan lain-lain." 46

Tambah Perdana Menteri lagi, kerajaan telah menubuhkan sebuah lembaga yang dinamakan Lembaga Perancang Keluarga Negara. Mengikut undang-undang perancang Keluarga Akta Parlimen Bil. 42 tahun $1966^{47}$ mensyaratkan bahawa sebuah lembaga hendaklah ditubuhkan yang terdiri daripada wakil-wakil dari jabatan-jabatan kerajaan dan wakil-wakil dari lapangan-lapangan tertentu. ${ }^{48}$ Antara ahli lembaga tersebut ialah seorang wakil daripada kolej Islam, Petaling Jaya. Lembaga ini berkuatkuasa mulai 1 jun 1966. Rancangan yang dijalankan ini tidak sekali-kali menyalahi hukum syara'. ${ }^{49}$ Walaupun tekanan dan pelbagai andaian yang mengaitkan aktiviti perancang keluarga ini menyalahi hukum syara', ${ }^{50}$ keputusan kerajaan bagi meneruskan aktiviti perancang keluarga di negara ini tetap diteruskan. ${ }^{51}$ Tun Abdul Razak menyatakan 'tidak ada sebarang perubahan dalam dasar dan pertubuhan perancang keluarga di Malaysia'. Program dan aktiviti perancang keluarga yang dirancang lima tahun lalu akan dijalankan seperti biasa. Ucapan ini dinyatakan semasa beliau bersiaran dengan Siaran Radio Luar Bandar bersama dengan Ketua Pengarah Lembaga Perancang Keluarga Kebangsaan Dato' Dr Ariffin Marzuki. ${ }^{52}$ Dalam tahun 1971 juga, beberapa kenyataan dibuat oleh Menteri Kesihatan Malaysia untuk menyatakan dasar kerajaan dalam pelaksanaan program ini. ${ }^{53}$

Di peringkat pelaksanaan, Program Perancang Keluarga Kebangsaan telah merancang program ini mengikut fasa-fasa tertentu bagi memastikan golongan sasaran dapat menerima program ini dengan terancang. ${ }^{54}$ Fasa program perancang keluarga kebangsaan memiliki empat fasa iaitu fasa pertama adalah meliputi kawasan bandar raya sahaja (1967-1968). Peringkat seterusnya melibatkan kawasan bandarbandar dan pekan-pekan kecil (1969). Fasa ketiga, program ini telah diperluaskan sehingga ke kawasan pusat kesihatan luar bandar (19701973) dan akhir sekali program ini dikembangkan lagi di peringkat terakhir iaitu melibatkan kawasan luar bandar yang telah diselenggara oleh pusat kesihatan luar bandar (1973). ${ }^{55}$

Bagi menjayakan aktiviti ini, Dato' Dr Ariffin (Ketua Pengarah Lembaga Perancang Keluarga Negara) berkata 'keutamaan akan diberikan kepada penyatuan perkhidmatan perancang keluarga dan Kementerian Kesihatan, ...banyak lagi klinik-klinik Perancang Keluarga dibina di kawasan luar bandar supaya ibu bapa senang untuk mendapatkan alat-alat perancang keluarga dengan mudah' ${ }^{56}$ Sehingga tahun 1975, pelbagai sokongan yang diberikan terhadap aktiviti perancang keluarga atau penduduk. Pada ketika itu, Tun 
Abdul Razak telah mengarahkan program-program yang bersifat kebangsaan supaya memberi penekanan terhadap penduduk luar bandar dan juga penduduk miskin. Hal ini bersesuaian dengan kegiatan yang dirancang oleh Lembaga Perancang Keluarga Negara (LPKN) ${ }^{57}$ dan PPK/PPPK. ${ }^{58}$ Kementerian Kesihatan mula mengorak langkah dengan memasukkan program perancang keluarga sepenuhnya dalam Perkhidmatan Kesihatan Ibu dan Anak di 59 daerah kesihatan luar bandar di Semenanjung Malaysia. Penyelarasan dan kerjasama yang erat antara LPKN dengan $\mathrm{KKM}^{59}$ digandingkan untuk faedah masa hadapan. ${ }^{60}$

Bagi memastikan aktiviti dan pelan tindakan perancang keluarga dapat dijalankan dengan baik, pemahaman awal diberikan terlebih dahulu kepada golongan kakitangan kesihatan bagi memastikan setiap kakitangan kesihatan dapat memberikan informasi yang lengkap mengenai program perancang keluarga. Program perancang keluarga adalah satu kaedah yang boleh dikategorikan sebagai kaedah pencegahan (preventif) yang dapat mencegah dan mengekang impakimpak negatif terhadap perkembangan ekonomi dan juga kesihatan penduduk di Malaysia. Bagi memulakan program ini, terdapat beberapa garis panduan yang dikeluarkan oleh Lembaga Perancang Keluarga Negara (LPKN) untuk dijadikan panduan. ${ }^{61}$ Tumpuan utama adalah memberi pemahaman kepada bidan-bidan kerajaan yang berkhidmat di kawasan luar bandar dalam mengetahui mengapa kerajaan melaksanakan dasar perancang keluarga. Aktiviti perancang keluarga mempunyai beberapa tujuan iaitu bagi memastikan ibu bapa dapat merancang bilangan anak yang mampu dilahirkan bergantung kepada tahap kesihatan ibu dan juga kemampuan pasangan terbabit untuk mendidik dan memastikan tahap kesihatan dan pelajaran anakanak mereka terjamin pada masa hadapan. ${ }^{62}$ Bagi memastikan setiap anak yang dilahirkan itu boleh diberi perhatian dengan baik, ibu bapa perlu memastikan agar anak yang dilahirkan itu sesuai dengan tahap kesihatan ibu bagi mengelakkan komplikasi terhadap ibu dan anak sewaktu proses bersalin. ${ }^{63}$

Terdapat pelbagai masalah yang diajukan oleh masyarakat yang masih lagi meragui program pencegahan kehamilan yang diperkenalkan oleh Kementerian Kesihatan bagi menjarakkan kehamilan. Oleh itu, pelbagai persoalan yang diajukan kepada Pegawai Perancang Keluarga mengenai kaedah penggunaan sarung getah (kondom) ${ }^{64}$ yang bimbang akan menjejaskan kesihatan dan kemaluan seseorang lelaki. Selain itu, cara penggunaan pil perancang keluarga, dan pelbagai kaedah lain juga turut dipersoalkan. Soalan-soalan yang diajukan ini kebiasaannya dibalas dan diberi penerangan yang jelas berserta dengan 
risalah mengenai perancang keluarga. ${ }^{65}$ Selain itu, masyarakat turut didedahkan dengan maklumat mengenai alat pencegah kehamilan seperti sarung getah, I.U.D. ${ }^{66}$ pil perancang keluarga ${ }^{67}$ penggunaan jelly atau $\mathrm{cream}^{68}$ dan pelbagai alat lagi yang boleh didapati di farmasi klinik perancang keluarga ${ }^{69}$ Selain penggunaan alat pencegahan kehamilan, ${ }^{70}$ aktiviti pendidikan kesihatan dan juga penekanan kesihatan ketika ibu mengandung juga perlu diberi perhatian.

Usaha yang dijalankan oleh kerajaan dalam memastikan kawalan pertumbuhan penduduk dapat dikawal dengan baik telah membuahkan hasil. Dalam tempoh 1966-1970, Lembaga Perancang Keluarga Kebangsaan (LPKK) $)^{71}$ telah menjalankan beberapa projek khususnya untuk menggalakkan pasangan menggunakan pil-pil perancang keluarga dan juga melatih kakitangan dalam perkhidmatan tersebut mengenai cara terbaik dalam memberi pengetahuan kepada pasangan suami isteri yang mahu merancang keluarga. Bagi memudahkan penyampaian informasi dan pendidikan perancang keluarga, ${ }^{72} \mathrm{klinik-}$ klinik perancang keluarga telah diwujudkan dan disediakan di hospitalhospital dan pusat-pusat kesihatan terutama di kawasan luar bandar. ${ }^{73}$

Bagi memastikan setiap penduduk terutama di kawasan pendalaman mendapat informasi mengenai perancang keluarga, klinik perancang keluarga bergerak turut diwujudkan dan mensasarkan penduduk yang berada di kawasan luar bandar. Langkah yang proaktif ini bertujuan untuk memastikan perkhidmatan perancang keluarga dapat disalurkan kepada 76 buah klinik tetap dan 413 buah klinik kecil di seluruh Semenanjung Malaysia dalam tempoh tahun 1966-1970. Perhatian juga turut diberikan terutama kepada penduduk di kawasan ladang-ladang kerana penduduk di kawasan ini masih belum didedahkan dengan perkhidmatan perancang keluarga. Sumbangan yang diberikan oleh LPKK juga dilihat semakin besar. Hal ini disebabkan Persatuan Perancang Keluarga turut menyumbang perkhidmatan mereka kepada 42 buah klinik dan 122 buah klinik bergerak. Dr Raja Ahmad Nordin (Pengarah Perkhidmatan Kesihatan Malaysia) menyatakan "...selain daripada itu, kerajaan mengadakan mobile team yang membawa doktor, jururawat dan sebagainya untuk melawat dan memberi rawatan di tempat-tempat terpencil" ${ }^{74}$ Persatuan ini turut terlibat aktif dalam memberikan perkhidmatan mereka di sekitar 148 buah kawasan ladang di seluruh Semenanjung Malaysia. ${ }^{75}$ Kementerian Kesihatan juga telah melakukan kerjasama dengan Kementerian Pembangunan Ekonomi Desa dalam mengadakan kempen dan aktiviti-aktiviti rancangan moden di kawasan yang tinggi kadar kematian bayi, kanak-kanak dan ibu bersalin, bagi mendidik dan memperbaiki nilai pemakanan penduduk terutama golongan ibu-ibu mengandung. ${ }^{76}$ 


\section{Keberkesanan Program Perancang Keluarga}

Sambutan yang diterima daripada penduduk mengenai program perancang keluarga ini amat memberangsangkan. Sejak bulan Mei 1967 sehingga tahun 1970, seramai 222000 orang telah mendaftarkan diri sebagai penerima program perancang keluarga. Berdasarkan statistik yang dikeluarkan oleh LPKK menyatakan seramai lebih $1 / 3$ daripada jumlah 222000 orang ini didaftarkan oleh pertubuhan sukarela terutamanya Persekutuan Persatuan-Persatuan Perancang Keluarga. Lebih kurang 63 peratus daripada peserta perancang keluarga ini terus menggunakan kemudahan yang disediakan oleh LPKK selepas 12 bulan dan sebanyak 44 peratus terus menggunakan perkhidmatan ini selepas 24 bulan. Program ini juga telah berjaya menarik minat ibu-ibu muda untuk mengamalkan perancang keluarga. Antara tahun 19671978, peratus penerimaan program ini dilihat berbeza mengikut usia golongan ibu. Jadual 2 di bawah memperincikan peratus penerimaan amalan perancang keluarga mengikut usia ibu. ${ }^{77}$

Jadual 2: Peratus Penerimaan Program Perancang Keluarga Secara Konsisten Mengikut Purata Umur Penerima

\begin{tabular}{|l|c|}
\hline Umur penerima & Peratus penerimaan \\
\hline 20-24 tahun & $89.40 \%$ \\
25-29 tahun & $75 \%$ \\
35-37 tahun & $34.30 \%$ \\
$40-44$ tahun & $15.30 \%$ \\
$45-48$ tahun & $3.50 \%$ \\
\hline
\end{tabular}

Sumber : Nor Laily Aziz, "Population And Family Planning Development-The Malaysian Experience", Seminar on Malaysian Fertility and Family Survey/Population and Development, Palm Beach Hotel, Pulau Pinang, 7-10 June, 1979, hlm. 18

Hasil kempen dan kemudahan yang disediakan oleh LPKK, telah menunjukkan kejayaan yang baik iaitu sebanyak 57,600 kelahiran bayi dapat dicegah dengan menggunakan pelbagai kaedah yang disarankan oleh LPKK. ${ }^{78}$ Aktiviti pencegahan kehamilan ini kebanyakannya adalah atas kerelaan pasangan suami isteri yang berminat dengan program pencegahan kehamilan yang diperkenalkan oleh persatuan perancang keluarga. Pada akhir tahun 1970, statistik mendapati bahawa sebanyak 78,400 kelahiran dapat dicegah. ${ }^{79} \mathrm{Hal}$ ini menunjukkan bahawa penduduk pada masa itu mulai sedar mengenai pendidikan perancang keluarga dalam memastikan tahap kesihatan dan ekonomi keluarga dapat dikawal dengan baik. 
Dalam jangka masa lima tahun antara tahun 1970-1975, matlamat Lembaga Perancang Keluarga adalah dengan menetapkan pertambahan penerima baharu. Semua agensi yang mengambil bahagian mempunyai satu matlamat iaitu menurunkan kadar kelahiran kepada 32 orang bagi setiap 1000 orang penduduk menjelang tahun $1975 .{ }^{80}$ Matlamat juga memfokuskan kepada penerima-penerima baharu dalam tempoh lima tahun iaitu sebanyak 600000 wanita yang berkahwin. Matlamat ini terus meningkat daripada 80000 pada tahun 1971 kepada 160000 pada tahun $1975 .{ }^{81}$ Dalam laporan yang dikeluarkan oleh LPKN pada tahun 1973 mendapati kadar pertambahan penerima baharu semakin meningkat. Walaupun berlaku peningkatan, objektif yang ingin dicapai masih belum sempurna kerana kadar kejayaan perancang keluarga dilihat menurun dari 68 peratus kepada 56 peratus pada tahun 1971 dan menurun lagi kepada 48 peratus pada tahun 1973. ${ }^{82}$ Kesan utama daripada aktiviti perancang keluarga yang dijalankan oleh kerajaan telah membawa kesan yang positif dari segi perkembangan penduduk. Secara keseluruhan, angka kelahiran bayi pada tahun 1972 dilihat menurun sedikit berbanding pada tahun 1971. Kadar kelahiran bagi kaum Melayu masih tidak dapat dikawal dengan baik kerana kelahiran kaum Melayu masih lagi meningkat sebanyak 1201 orang pada tahun 1972. Berdasarkan Jadual 3 di bawah menunjukkan kadar kasar kelahiran mengikut kaum bagi tahun yang dinyatakan:

Jadual 3: Peratusan Kadar Kasar Kelahiran Bagi Tiap-Tiap 1000 Penduduk Mengikut Kaum

\begin{tabular}{|c|c|c|c|c|}
\hline Tahun & Melayu & Cina & India & Lain-lain \\
\hline 1957 & 48.1 & 43.3 & 49.7 & 30.4 \\
1968 & 39.2 & 33.5 & 36.5 & 34.2 \\
1969 & 36.8 & 31.7 & 34.7 & 31.1 \\
1970 & 35.4 & 32 & 33.3 & 25.6 \\
1971 & 36.2 & 32.4 & 31.9 & 25.5 \\
1972 & 35.4 & 31 & 31.2 & 23.4 \\
\hline
\end{tabular}

Sumber: Dipetik daripada 'Kelahiran Menurun' dalam Bulitin Keluarga, Siaran Lembaga Perancang Keluarga Negara Malaysia, 1975-1983.

Jadual 3 menunjukkan kadar kelahiran bagi kaum-kaum di Malaysia. Kaum Melayu menunjukkan kadar penurunan kelahiran walaupun jumlahnya tidak begitu tinggi berbanding dengan 
kaum-kaum lain. Kadar penurunan ini adalah hasil daripada kesungguhan kerajaan dalam menjalankan kempen perancang keluarga. Keseimbangan perkembangan penduduk dan peningkatan taraf kesihatan negara menjadi keutamaan negara selaras dengan kadar perkembangan ekonomi negara. Oleh itu, program perancang keluarga ini adalah satu langkah yang sangat berkesan dalam mengawal jumlah pertumbuhan penduduk. Hasil kejayaan dapat dilihat menerusi Jadual 4 yang menunjukkan peratus kadar kelahiran penduduk yang semakin menurun dari tahun 1957-1975.

Jadual 4: Kadar Peratus Kelahiran di Semenanjung Malaysia tahun 1957-1975

\begin{tabular}{|c|c|c|c|}
\hline Tahun & Peratus Kelahiran & Tahun & Peratus Kelahiran \\
\hline 1957 & 46.2 & 1966 & 37.3 \\
1958 & 43.3 & 1967 & 35.3 \\
1959 & 42.1 & 1968 & 35.4 \\
1960 & 40.9 & 1969 & 33.3 \\
1961 & 41.8 & 1970 & 32.5 \\
1962 & 40.3 & 1971 & 33 \\
1963 & 39.4 & 1972 & 32 \\
1964 & 39.1 & 1973 & 30.7 \\
1965 & 36.7 & 1974 & 30.9 \\
& & 1975 & 30.3 \\
\hline
\end{tabular}

Sumber: Nor Laily Aziz, "Population And Family Planning Development-The Malaysian Experience", Seminar on Malaysian Fertility and Family Survey/Population and Development, Palm Beach Hotel, Pulau Pinang, 7-10 June, 1979, hlm.11.

Selain pengurangan kadar pertumbuhan penduduk, kesan positif juga dapat dilihat menerusi kadar pengurangan kematian kanakkanak yang berumur satu hingga empat tahun. Pengurangan ini disebabkan program perancang keluarga yang menitikberatkan amalan menjarakkan kehamilan bagi memberi masa kepada ibu untuk memberi perhatian kepada anak yang dilahirkan. Jadual 5 menunjukkan kadar kematian kanak-kanak yang semakin berkurangan mengikut tahun: 


\section{Jadual 5: Kadar Kematian Kanak-Kanak di Semenanjung Malaysia Mengikut Tahun-Tahun Tertentu}

\begin{tabular}{|l|c|}
\hline Tahun & Peratus Kadar Kematian Kanak-kanak 1-4 tahun \\
\hline 1966 & 5,699 orang / 5.07 peratus \\
1970 & 4,837 orang / 4.20 peratus \\
1974 & 3,641 orang / 3.13 peratus \\
1975 & 3,032 orang / 2.56 peratus \\
\hline
\end{tabular}

Sumber: Nor Laily Aziz, "Population And Family Planning Development-The Malaysian Experience", Seminar on Malaysian Fertility and Family Survey/Population and Development, Palm Beach Hotel, Pulau Pinang, 7-10 June, 1979, hlm. 20.

Kesan positif juga dapat dilihat dari segi penurunan kes kematian ibu sewaktu proses bersalin. Penurunan kes ini dilihat sebagai satu impak yang positif bagi menjamin keselamatan ibu sewaktu proses bersalin. Jadual 6 menunjukkan penurunan peratus kematian ibu bersalin:

Jadual 6: Peratus Kematian Ibu Bersalin di Semenanjung Malaysia Mengikut Bangsa yang Dinisbahkan kepada setiap 1000 Kelahiran

\begin{tabular}{|c|c|c|c|c|}
\hline Tahun & Melayu & Cina & India & Jumlah \\
\hline 1957 & 3.99 & 1.4 & 2.05 & 2.83 \\
\hline 1970 & 2.15 & 0.48 & 1.16 & 1.48 \\
\hline 1976 & 1.19 & 0.18 & 0.43 & 0.78 \\
\hline Peratus penurunan & 70.20 peratus & 87.10 peratus & 79 peratus & 72.30 peratus \\
\hline
\end{tabular}

Sumber: Nor Laily Aziz, "Population And Family Planning Development-The Malaysian Experience", Seminar on Malaysian Fertility and Family Survey/Population and Development, Palm Beach Hotel, Pulau Pinang, 7-10 June, 1979, hlm, 17.

Berdasarkan Jadual 6, keupayaan program perancang keluarga ini dianggap satu program yang berjaya mengurangkan kadar peratusan kelahiran, kematian bayi dan juga kematian ibu bersalin. Kesan positif ini dapat diukur berdasarkan jadual yang dinyatakan di atas. Kejayaan program ini dapat dicapai dalam masa yang singkat atas usaha yang dimainkan oleh pihak kerajaan dan juga badan yang bertanggungjawab.

\section{Kesimpulan}

Program perancang keluarga adalah satu program yang diperkenalkan oleh kerajaan bagi mengawal pertumbuhan penduduk dengan lebih terkawal. Kesan utama yang dapat dilihat daripada pengenalan 
program ini ialah kadar pertumbuhan penduduk dapat dikawal dengan baik. Matlamat kerajaan bertujuan untuk memacu perkembangan ekonomi selaras dengan pertumbuhan penduduk. Peratus pengurangan pertumbuhan penduduk dilihat semakin menurun apabila kerajaan memutuskan untuk menjadikan program perancang keluarga sebagai salah satu dasar negara.

Secara umumnya, masyarakat mula menyambut baik usaha yang telah diperkenalkan oleh pihak kerajaan dengan melibatkan diri dalam aktiviti dan kempen yang dijalankan oleh pihak yang bertanggungjawab. Dari aspek kesihatan pula, kes-kes kematian ibu dan bayi semasa dilahirkan juga turut berkurangan dari tahun ke tahun kesan pengurangan kadar kekerapan kelahiran yang diamalkan oleh pasangan suami isteri. Pada keseluruhanya, program perancang keluarga telah memberikan hasil yang positif kepada perkembangan kesihatan penduduk, seterusnya telah menjamin kestabilan ekonomi negara yang pada ketika itu masih lagi dalam proses untuk membangun. Program perancang keluarga dilihat sebagai salah satu ikhtiar yang dilakukan oleh kerajaan bagi mewujudkan sebuah kehidupan yang sistematik. Program ini bukan berniat untuk menolak qada dan qadar tetapi tujuan utamanya adalah untuk memberi ruang kepada keluarga bagi mengatur kehidupan yang lebih baik dan selesa. Hal ini kerana masyarakat yang sihat adalah aset yang berharga selain dapat menjamin kesejahteraan dan kemajuan negara.

\section{Nota}

1 Steven W. Sinding, "Overview and perspective", dalam Warren C.Robinson, John A. Ross, The Global Family Planning Revolution, Three Decades of Population Policies and Programs, Washington: The World Bank, 2007, hlm. 1.

Ibid, hlm. 2.

"The Voluntary Family Planning Movement", dalam Studies in Family Planning, Vol.10, No. 1, Kuala Lumpur: Persekutuan Perancang Keluarga Malaysia (PPPKM), 1979, hlm. 3.

$4 \quad$ Nai Peng Tey, "The Family Planning in Penisular Malaysia", dalam Warren C.Robinson, John A. Ross, The Global Family Planning Revolution, Three Decades of Population Policies and Programs, Washington: The World Bank, 2007, hlm. 259-260.

"The Voluntary Family Planning Movement", hlm. 3.

Nai Peng Tey, "The Family Planning in Penisular Malaysia”, hlm. 260.

"The Voluntary Family Planning Movement", hlm. 3.

Nai Peng Tey, "The Family Planning in Penisular Malaysia", hlm. 259-260. Tun Hj Abdul Razak Hussein, "Government Policy on Birth Control in Malaysia", dalam Economic Association of Malaysia, Kajian Ekonomi Malaysia, Volume III dan IV, No. 1-2, 1966-1967, hlm. 3-4. 
Ibid.

Speech by Deputy Prime Minister Tun Hj Abdul Razak at The Launching Ceremony of The National Family Planning Board in Dewan Tunku Abdul Rahman, 10 Jun 1966.

Fail No. 2.00 246/2, Population, Development, and Welfare in Malaya, dalam, Sub-Committee of The Cabinet To Consider The Policy On Family Planning, (Jabatan Perdana Menteri), hlm. 1.

Pada tahun 1970, kajian telah dilakukan dan mendapati lebih kurang 50 peratus daripada keluarga di Semenanjung Malaysia berada di bawah paras kemiskinan (purata pendapatan RM 264 sebulan), daripada jumlah tersebut, sebanyak 86 peratus golongan miskin ini terdiri daripada penduduk luar bandar dan merupakan orang Melayu. Kebanyakan penduduk ini menetap di negeri-negeri majoriti Melayu seperti Kedah, Kelantan, Terengganu dan Perlis. Lihat, Nor Laily Aziz, Penduduk, Perancang Keluarga dan Wanita, Kuala Lumpur: Lembaga Perancang Keluarga Negara, 1979, hlm.1.

Fail No.2.00 246/2, The Malaya Situation, in Population, Development, and Welfare in Malaya, Sub-Committee of The Cabinet To Consider The Policy On Family Planning, (Jabatan Perdana Menteri), hlm. 1.

Ibid.

Masalah ekonomi yang melanda negara adalah berpunca daripada faktor kejatuhan harga getah dan peningkatan jumlah pengangguran. Keadaan ini telah mengubah pendirian kerajaan terhadap keperluan Program Perancang Keluarga. Lihat, Nai Peng Tey, “The Family Planning in Penisular Malaysia", dalam, Warren C.Robinson, John A. Ross, The Global Family Planning Revolution, Three Decades of Population Policies and Programs, Washington: The World Bank, 2007, hlm. 260.

Fail No. 2.00 246/2, Population, Development, and Welfare in Malaya, dalam, Sub-Committee of The Cabinet To Consider The Policy On Family Planning, ( Fail Jabatan Perdana Menteri), hlm.1.

Angka indeks digunakan untuk mengukur secara kuantitatif terjadinya sebuah perubahan dalam dua waktu yang berlainan. Bagi menilai angka indeks memerlukan dua waktu iaitu waktu dasar (base period) dan waktu yang berkaitan atau sedang berlangsung (current period). Lihat, Anto Dajan, Pengantar Metode Statistik, Jakarta :Lembaga Penelitian, Pendidikan dan Penerangan Ekonomi dan Sosial, 1975-1976, hlm. 72.

Ibid.

Mengikut laporan yang dikeluarkan oleh Lembaga Perancang Keluarga Negara menyatakan pada tahun 1970, kawasan luar bandar mencatatkan kadar kematian bayi yang tinggi. Sebagai contoh di kawasan Ulu Kelantan mencatatkan kadar kematian 70-110 setiap 1000 kelahiran. Manakala di kawasan Tanah Merah, Ulu Terengganu, Maran, dan Kemaman mencatatkan kematian bayi sebanyak 60-69 kematian setiap 1000 kelahiran. Bagi kematian ibu bersalin pula, daerah Kemaman mencatatkan jumlah tertinggi kematian ibu bersalin iaitu 5-7 kematian bagi setiap 1000 ibu bersalin. Bagi kawasan lain seperti Selama (Perak), Ulu Perak, Tanah Merah, Machang, Ulu Kelantan, Ulu Terengganu, Jerantut dan 
Raub mencatatkan jumlah kematian ibu bersalin sebanyak 3-5 kematian bagi setiap $1000 \mathrm{ibu}$ bersalin. Bagi keseluruhan Semenanjung Malaysia pada tahun 1970, dianggarkan kadar kematian sebanyak 2.06 peratus bagi tiap-tiap 1000 ibu bersalin. Rujuk laporan, Hashim Yunus (Ketua Bahagian Penerangan LPKN), Perancang Keluarga, Satu Ikhtiar Membela Nasib Masyarakat, Lembaga Perancang Keluarga Negara, 1976, hlm. 10-11. Lihat, 'Perkhidmatan Kesihatan Diperluas Lagi', Bulitin Keluarga, Siaran Lembaga Peranchang Keluarga Kebangsaan Malaysia, Edisi November/ Disember 1973, hlm. 4.

Ibid.

23 Ibid

24 Lihat, 'Ibu-ibu di Kelantan ramai yang mati bersalin', Bulitin Keluarga, November/Disember 1973, hlm. 12.

25 Lihat 'Dasar Peranchang Keluarga-Tidak ada Perubahan' dalam Bulitin Keluarga, No 30, 32-39, 41, Januari, March, 0ktober, \& Disember, 1971, hlm. 7.

Pada tahun 1964, jawatankuasa kecil kabinet telah dibentuk dan diketuai oleh Khir Johari bagi mengkaji perkembangan penduduk dan kesannya ke atas negara. Hasil laporan kajian diteliti untuk dipertimbangkan sebagai salah satu polisi negara. Lihat, Nai Peng Tey, "The Family Planning in Penisular Malaysia", hlm. 259-260.

Lihat, Kesihatan dan Peranchang Keluarga, dalam Rancangan Malaysia Kedua 1971-1975, Jabatan Cetak Kerajaan, Kuala Lumpur, 1971, hlm. 275. Fail No, 2.00 246-2, Proposal for the Setting up of a Family Planning Board in Malaysia, dalam, Sub-committee of the Cabinet to Consider the Policy on Family Planning, Jabatan Perdana Menteri, hlm. 3. Ibid.

30 Persekutuan Persatuan-Persatuan Perancangan Keluarga ataupun dalam bahasa Inggerisnya dikenali sebagai The Federation of Family Planning Associations merupakan peneraju utama kepada pertubuhan-pertubuhan sukarelawan persatuan perancang keluarga. Rujuk, Fail No. 2.00 246-2, Sub-Committee of The Cabinet To Consider The Policy On Family Planning, dalam Proposal for the Setting up of a National family Planning Board in Malaysia. ( Jabatan Perdana Menteri), hlm. 2. Ibid.,hlm. 2-3.

32 Pada peringkat permulaan perancangan program perancang keluarga, sebuah badan sukarela dicari bagi membantu kerajaan merangka program ini. Kerajaan telah memberi sejumlah geran tahunan sebanyak \$200 000 kepada organisasi sukarela yang akan bertanggungjawab menyelaras program ini.Organisasi sukarela ini adalah terdiri daripada Persekutuan Persatuan-Persatuan Perancang Keluarga yang merupakan penggerak utama kepada persatuan-persatuan perancang keluarga yang telah wujud di negara ini. Lihat, Fail No, 2.00 246-2, Proposal for the Setting up of a Family Planning Board in Malaysia, dalam, Sub-committee of the Cabinet to Consider the Policy on Family Planning, (Jabatan Perdana Menteri), hlm. 3.

33 Ibid

34 Annual Report, Ministry Of Health Malaysia 1973-1974, hlm. 96. 
Fail No. (2.00) 246-2, Proposal for the Setting up of a National family Planning Board in Malaysia, (Jabatan Perdana Menteri), hlm. 2-3.

Ibid.

37 Lembaga Perancang Keluarga Negara merupakan sebuah badan rasmi berkanun di bawah Jabatan Perdana Menteri mempunyai fungsi dan tanggungjawab dalam melaksanakan tugasnya iaitu:

- Menetapkan dasar, cara-cara memberi galakan, menyebarkan pengetahuan dan amalan perancang keluarga berasas kepada kesihatan ibu-ibu dan anak-anak dan kebajikan sesuatu keluarga.

- Menyiapkan dan melaksanakan rancangan berkaitan perancang keluarga negara.

- Bertanggungjawab memberi latihan kepada anggota yang terlibat dalam aktiviti perancang keluarga.

- Mengadakan penyiasatan cara perubatan biologi yang berkaitan dengan perancang keluarga.

- Menjalankan siasatan dan kajian berkaitan dengan sosial, kebudayaan, dan perubahan ekonomi dan jumlah penduduk.

- Menubuhkan satu sistem penilaian dan mengkaji dari masa ke masa mengenai kemajuan rancangan ini.

- Melantik pegawai dan kakitangan mengikut syarat yang telah diluluskan oleh Menteri yang berkenaan.

Rujuk, Laporan Tahunan 1976, Lembaga Perancang Keluarga Negara, hlm. 4 dan 21.

Ibid.

Ibid.

Kenyataan ini tidak dipersetujui oleh seorang ahli parti Perikatan di Parlimen iaitu Tuan Haji Ahmad bin Abdullah (Senator dari Pulau Pinang, tahun 1966) yang berpendapat jika program perancang keluarga dirancang bagi mengalakkan pasangan merancang bilangan keluarga tanpa paksaan (sukarela), mengapa kerajaan menjadikan program perancang keluarga ini sebagai satu akta rasmi? Keterangan lanjut, rujuk, Fail No, (2.00) 246-2, "The Changing Official Attitude to Family Planning", dalam, SubCommittee of the Cabinet to Consider the Policy on Family Planning.(Jabatan Perdana Menteri), hlm. 11.

41 Aktiviti perancang keluarga juga menjadi isu yang hangat dalam kalangan ahli UMNO kerana mereka melihat usaha ini memberi kesan terutama dalam aspek perkembangan penduduk Melayu.Selepas peristiwa Mei 1969, kedudukan politik Melayu semakin lemah. Bilangan penduduk kaum Melayu harus ditambah bagi mengekalkan kuasa politik orang Melayu.Ibid. hlm. 16.

42 Beberapa pendapat yang dikeluarkan yang menjelaskan mengenai perancang keluarga:

- $\quad$ Fatwa oleh Tuan Hj Ali Bin Mohd Said Salleh (Qadi, Singapura) berpendapat, tindakan menghalang wanita daripada melahirkan anak adalah salah dalam agama Islam (Utusan Melayu 1955) 
- $\quad$ Fatwa oleh Hj Abdul Jalil b. Hj Hassan (Timbalan Mufti Johor 1965) menyatakan penggunaan dadah dan bahan berbahaya dalam pil dilarang kerana boleh menyebabkan ketidaksuburan kekal.

Rujuk, Fatwas on Muslim Savants, dalam Studies in Family Planning, Vol. 10, No. 1, Kuala Lumpur: Persekutuan Perancang Keluarga Malaysia (PPPKM), 1979, hlm. 2-4.

Menolak qada dan qadar Allah S.W.T mengikut tafsiran Al Sayyid Yusuf bin Ali al Zawawi (Mufti Kerajaan Terengganu, 1966) menyatakan golongan ibu bapa yang menyatakan alasan tidak mahu melahirkan anak walaupun berkeadaan sihat, tiada masa untuk memberi perhatian, mengelak dari memberi tanggungjawab dan tidak mahu mengandung bagi tujuan mahu mengekalkan kecantikan dikategorikan sebagai haram. Ibid, hlm. 2.

Tuan Haji Abu Bakar Bin Hamzah merupakan seorang Ahli Parlimen dari parti PAS yang mewakili kawasan Bachok Kelantan selepas memenangi pilihanraya kecil Bachok pada tahun 1964. Mesyuarat Dewan Rakyat, Parlimen Kedua, Sesi keempat, 17 0ktober 1967. Ibid.

Lembaga Perancang Keluarga Negara telah mula dikuatkuasakan mulai 10 Julai 1966. Lihat, Laporan Tahunan Lembaga Perancang Keluarga Negara 1973, hlm. 3.

Mengikut Akta ini, ahli lembaga adalah terdiri daripada seorang pengerusi yang dilantik oleh D.Y.M.M Seri Paduka Baginda Yang Dipertuan Agung, seorang Pengarah yang dilantik oleh YAB Perdana Menteri, iaitu Menteri yang bertanggungjawab terhadap perancang keluarga dan tidak lebih 20 orang ahli-ahli lain. 10 orang wakil kementerian dan 10 orang mewakili orang awam. Ibid. Jawapan lisan oleh Tun Abdul Razak bagi menjawab pertanyaan Tuan Haji Abu Bakar Bin Hamzah dalam Mesyuarat Dewan Rakyat, 17 0ktober 1967.

$50 \quad$ LPKN menubuhkan satu unit agama bagi mengalas tugas untuk memberi syarahan dalam kursus anjuran LPKN.Sepanjang tahun 1976, sebanyak 95 siri ceramah dan dialog dilakukan. Maklum balas yang dilaporkan oleh pegawai unit agama ini memperincikan mengenai masalah yang dihadapi oleh mereka dalam berhadapan dengan beberapa golongan yang menentang amalan perancang keluarga. Antara masalah dan andaian yang sentiasa ditimbulkan adalah seperti berikut:

- $\quad$ Penduduk kampung yang masih lagi berpegang dengan konsep 'ulat dalam batu ada rezeki' dan 'rezeki secupak tidak akan jadi segantang'. Mereka juga berpegang teguh dengan pendirian ketua kampung, lebai dan imam sebagai penasihat mereka.

- $\quad$ Terdapat juga ahli politik yang menyokong perancang keluarga secara luaran, tetapi secara tersiratnya mereka menentang.

- Ramai golongan ulamak menentang perancang keluarga dan menjadi ikutan orang Melayu. 
- $\quad$ Ramai golongan intelek Islam masih tidak memahami tentang perancang keluarga.

- Terdapat juga Jabatan Agama yang tidak bersetuju dengan perancang keluarga.

- Jabatan Agama Negeri Perak telah mengeluarkan fatwa dan menyebarkan kepada umum melalui khutbah Jumaat yang menyatakan 'perancang keluarga haram

Faktor di atas merupakan faktor utama yang mempengaruhi pendirian penduduk dalam memberi persepsi negatif terhadap perancang keluarga. Rujuk, Lembaga Perancang Keluarga Negara, Lapuran Tahunan 1976, National Family Planning Board Malaysia, hlm. 26.

51 Persekutuan Persatuan-Persatuan Perancang Keluarga Malaysia telah mengeluarkan artikel yang menerangkan mengenai pendapat ahli-ahli agama dalam menyatakan kebenaran setiap penganut agama yang mahu merancang kelahiran anak berdasarkan sebab-sebab tertentu. Dalam artikel ini ada menyentuh setiap pendapat dari kepelbagaian agama seperti agama Islam, agama Kristian, Hindu dan Buddha. Rujuk, Religious Attitudes Toward Birth Control, Information Services, Persekutuan Persatuan Persatuan Perancang Keluarga Malaysia, Kuala Lumpur. 1977, hlm. 1-4. Lihat, 'Dasar Peranchang Keluarga Tidak Ada Perubahan', dalam Buletin Keluarga , No 30,32-39, 41 - Januari, Mac-Oktober, Disember 1971, hlm. 7. Tan Sri Sardon menyatakan "... even after complete integration of family planning into rural health services, only half of the rural target group will be covered. This means that the rural health services, will have to be strengthened if family planning intergration is to be successfully implemented. ... the five years from 1971-1975 will see intensifield activities in the rural areas in the family planning field. At the centre of these activities will be the Medical Officer as well as the Health Officer, on whom leadership and drive will reflect the success or failure of our programme. To prepare future young doctors for this important role, training is necessary in the medical schools in family planning, human reproduction and population dynamic, geared to local conditions." Lihat, Family Planning's Vital Role in Health Services by Tan Sri Sardon Jubir, dalam Bulitin Keluarga, Siaran Lembaga Peranchang Keluarga Kebangsaan Malaysia, Disember 1971.

54 Di bawah Rancangan Malaysia Pertama dan Rancangan Malaysia Kedua, program perancang keluarga telah memfokuskan mengenai program bagi meningkatkan perkembangan sosial dan ekonomi penduduk di negara ini. Dalam rancangan ini, kerajaan percaya bahawa kadar pertumbuhan penduduk yang perlahan akan memberi keupayaan kepada kerajaan dalam memberi perhatian kepada perkembangan ekonomi . Oleh itu, terdapat beberapa objektif utama yang perlu dicapai oleh Program Perancang Keluarga Kebangsaan untuk meningkatkan usaha kerajaan dalam memperkembangkan kebajikan dan kesihatan keluarga, mempromosikan perkembangan sosial bagi mengalakkan produktiviti pekerja, mengurangkan jurang pendapatan antara penduduk, meningkatkan kadar keselesaan tempat tinggal, mewujudkan nilai persekitaran yang baik, menyelesaikan masalah kesan daripada 
pembangunan tanah, dan juga meyelesaikan pengurusan alam sekitar. Lihat, Nor Laily Aziz, Population And Family Planning Development-The Malaysian Experience, Seminar on Malaysian Fertility and Family Survey/ Population and Development, hlm. 8.

Ibid.

Lihat, 'Dasar Peranchang Keluarga Tidak Ada Perubahan', dalam Buletin Keluarga , No 30,32-39, 41 - Januari, Mac-Oktober, Disember 1971, hlm. 7. Rujuk, Lapuran Tahunan 1976, Lembaga Perancang Keluarga Negara, hlm. 4 dan 21.

PPPK adalah singkatan kepada Persekutuan Persatuan-Persatuan Perancang Keluarga yang merupakan sebuah pertubuhan sukarela yang mengambil berat mengenai keadaan kesihatan seseorang, keluarga dan bangsa. PPPK ditubuhkan pada tahun 1958 dan merupakan pecahan dari satu persekutuan dan mempunyai 11 Persatuan Perancang Keluarga (PPK) Negeri di Semenanjung Malaysia. Antara objektif utama PPPK ialah bagi menambah pengetahuan awam dan kefahaman mengenai perancang keluarga dan penduduk bermaksud untuk memperbaiki keadaan-keadaan kesihatan keluarga dan kualiti kehidupan manusia, PPPK juga berfungsi sebagai sebuah pertubuhan yang menambah dan melengkapi perkhidmatan rancangan-rancangan keluarga kebangsaan kerajaan melalui perbekalan perancang keluarga dan perkhidmatan yang berkaitan contohnya, kesuburan, pemeriksaan penghamilan, pemeriksaan Pap Smear Test utama melalui PPK negeri. PPPK juga bertindak sebagai wakil dan badan penyelarasan kepada pergerakan perancang keluarga sukarela pada peringkat kebangsaan dan antarabangsa. Dengan kata mudah, PPPK ini bergiat secara aktif dalam aktiviti yang melibatkan soal perancang keluarga di peringkat kebangsaan dan juga peringkat negara. Lihat, Federation of Family Planning Associations Malaysia (FFPAM), Annual Report 1975, hlm. 4.

Walaupun Lembaga Perancangan Keluarga Negara bertanggungjawab secara keseluruhan untuk aktiviti perancangan keluarga, Kementerian Kesihatan telah mengambil tanggungjawab menyediakan perkhidmatan perancangan keluarga di kawasan luar bandar sebagai sebahagian daripada penjagaan kesihatan keluarga secara komprehensif sejak tahun 1971. LPKN pula telah mengunakan unit-unit dan kemudahan yang dimiliki oleh KKM seperti klinik, pusat kesihatan ibu dan lain-lain sebagai tempat untuk melaksanakan aktiviti kempen perancang keluarga. Lihat, Annual Report, Ministry of Health Malaysia 1973-1974, hlm. 96. Ibid.

LPKN (A) 3/1-3 PR, Projek Bidan Kampung. Kementerian Kesihatan Malaysia, hlm. 1.

Ibid.

Ibid., hlm. 2- 4.

Bagi menarik minat kaum lelaki menggunakan kondom, pihak industri pengeluar kondom telah mempelbagaikan variasi kondom iaitu mengeluarkan kondom yang memiliki ciri yang pelbagai seperti warna kabur, biru, hijau, merah, kuning, hitam, berbentuk transparen, hujung 
rata, hujung berpundi, berbentuk pagoda, bahagian luar yang kasar, kering, berperasa buah-buahan, berminyak, bertepung dan memiliki pelbagai variasi saiz. Dalam laporan "kondom untuk lelaki" Buletin Kesihatan Keluarga, Siaran Lembaga Perancang Keluarga Negara Malaysia, 1975, hlm. 5.

Buletin Keluarga merupakan satu risalah yang banyak membincangkan mengenai perancang keluarga, sebanyak 8000 naskah dikeluarkan setiap bulan yang menggunakan bahasa Melayu dan bahasa Inggeris. Kebanyakan berita-berita ini juga ditulis dalam akhbar-akhbar tempatan. Pada tahun 1974, Buletin Keluarga juga turut menyediakan risalah dalam bahasa Mandarin dan juga bahasa Tamil. Selain risalah, siaran sebaran am yang digunakan meliputi sisipan dalam akhbar Melayu, Cina, Tamil dan Inggeris, sebaran dalam rancangan televisyen pelbagai bahasa dan juga radio pelbagai bahasa. Rujuk, Laporan Tahunan Lembaga Perancang Keluarga Negara 1973, hlm. 56-57.

I.U.D (Intra.Uterine.Device) adalah sejenis alat yang dimasukkan ke dalam faraj ibu. Alat ini diperbuat daripada plastik dan hanya akan dapat dimasukkan ke dalam faraj oleh orang yang pakar (doktor).

Lebih kurang 95.5 peratus daripada penerima menggunakan pil yang diperbuat dari bahan pro-gestron dan estrogen yang memberi kesan dalam menghalang ovulasi dan menyebabkan perubahan pada endometrium sehingga tidak terjadi nidosi dari telur, kesan pil juga menyebabkan kewujudan lendir dari servik yang menyebabkan spermatozoa sukar untuk melaluinya. Pil-pil dijual kepada penerima perancang keluarga dengan harga $\$ 1$ bagi setiap satu pusingan pil. Bagi penerima yang tidak berkemampuan untuk membeli, pil ini diberi secara percuma. Pada tahun 1975, LPKK telah menjual sebanyak 2, 038, 133 pil pencegah kehamilan dan 6, 397 gross sarung getah (kondom) kepada penerima program perancang keluarga. Lihat, Laporan Tahunan Lembaga Perancang Keluarga Negara1976, National Family Planning Board Malaysia, hlm. 7.

68 Penggunaan jelly atau cream adalah penggunaan bercorak kimia yang digunakan untuk mematikan dan melemahkan sperma semasa berada di dalam faraj. Sebelum persetubuhan, krim ini akan dimasukkan dan disapu ke dalam saluran faraj.

69 Bagi memastikan bekalan bahan perancang keluarga sentiasa mencukupi, bahagian pembekalan diberi tanggungjawab dalam menjalankan pengawalan dalam bidang penempahan, pembelian, pengimportan, dan membekalkan bahan-bahan perancang keluarga di seluruh Semenanjung Malaysia. Bekalan ini disalurkan kepada estet-estet, doktor persendirian, persatuan perancang keluarga, klinik-klinik dan lain-lain badan yang menyertai rancangan perancang keluarga. Terdapat beberapa jenis bahan yang menjadi keutamaan dalam merancang keluarga iaitu penggunaan pil Eugynon ED-Fe, Gynovlar-21, dan Ovulen $50 \mathrm{Fe}$-28. Selain penggunaan pil perancang, kaedah penggunaan alat-alat tertentu juga digunakan seperti Alat Dalam Rahim (IUD), suntikan Depo-Provera, dan juga sarung getah (kondom). Bahan-bahan ini semua diperolehi dari bantuan SIDA (Swedish International Development Authority). Lihat, Laporan Tahunan 
Lembaga Perancang Keluarga Negara 1973, hlm. 10. Peranan yang dimainkan oleh SIDA melalui perjanjian antara Kerajaan Sweden dengan Kerajaan Malaysia, juga boleh dirujuk, Fail No.(2.00) 246-1, Family Planning / Birth Control, Family Planning in Malaysia- Policy. (Jabatan Perdana Menteri). Pada tahun 1975 mencatatkan penerimaan penggunaan alat pencegahan kehamilan yang tertinggi adalah melalui penggunaan pil perancang keluarga (87.6 peratus), memotong saluran tiub falopio (5.3 peratus), pengunaan IUD (1.3 peratus), kaedah suntikan (5.8 peratus), penggunaan kondom (5.4 peratus), dan akhir sekali kaedah meyekat saluran mani dari testis ke zakar ( 0.4 peratus). Lihat, Lim Lin Lean, "Family Planning Services In The Private Sector: A Case Study Of Harrisons \& Crosfield Estates In West Malaysia", Tesis Ph.D, Universiti Malaya, Kuala Lumpur, 1981, hlm. 176.

71 Lembaga Perancang Keluarga Kebangsaan (LPKK) merupakan sebuah lembaga yang diwujudkan selaras dengan dasar yang termaktub dalam Akta Parlimen No. 46 tahun 1966. Fungsi yang dilaksanakan oleh LPKK ini dilihat lebih menjurus kepada perancangan untuk menambahkan bilangan klinik perancang keluarga, mensasarkan peningkatan jumlah penerima baharu dan juga bermatlamat untuk memperluas perkhidmatan ke kawasan luar bandar. Perbezaan antara LPKN dan LPKK dilihat tidak jauh berbeza. LPKN dilihat sebagai sebuah badan yang merangka dasar, melatih, melantik pegawai, dan menjalankan kajian. LPKK pula lebih bersifat sebagai badan pelaksana. Lihat, Lembaga Perancang Keluarga Kebangsaan, dalam, Malaysia 1970 Buku Rasmi Tahunan, jilid keempat, Jabatan Chetak Kerajaan 1972, hlm. 82-83. Lihat, 'Kejayaan Chermerlang Lembaga Peranchang Keluarga Kebangsaan', Bulitin Keluarga , No 30,32-39,\& 41, Januari, March, 0ctober,\& Disember 1971, hlm. 3.

73 Dalam tahun 1971, Lembaga Perancang Keluarga Negara bersetuju pada dasarnya untuk menyediakan perkhidmatan yang berkesan di luar bandar.Dari tahun 1971-1972, sebanyak lapan buah daerah kesihatan luar bandar telah dipilih dalam Rancangan Intergrasi.Pada tahun 1973, perkhidmatan ini terus diperluaskan lagi dengan merancang program integrasi untuk 14 buah lagi daerah kesihatan tambahan di seluruh Semenanjung Malaysia.Laporan Tahunan Lembaga Perancang Keluarga Negara 1973, National Family Planning Board Malaysia, hlm. hlm. 41. Lihat, 'Perkhidmatan Kesihatan Diperluaskan Lagi', dalam Bulitin Keluarga. Edisi Nov/Dis, 1973, hlm. 4. Lihat, 'Kejayaan Chermerlang Lembaga Peranchang Keluarga Kebangsaan', dalam Bulitin Keluarga , No 30, 32-39,\& 41, Januari, March, 0ktober, \& Desember, 1971, hlm. 3.

76 Lihat, 'Perkhidmatan Kesihatan Diperluaskan Lagi', dalam Bulitin Keluarga. Edisi Nov/Dis, 1973, hlm. 4.

77 Nor Laily Aziz, "Population And Family Planning Development-The Malaysian Experience", dalam seminar, Malaysian Fertility and Family Survey/Population and Development, Palm Beach Hotel, Pulau Pinang, 7-10 Jun, 1979, hlm. 18. 
78 Lihat, Kesihatan dan Peranchang Keluarga, dalam Rancangan Malaysia Kedua 1971-1975, Jabatan Cetak Kerajaan, Kuala Lumpur, 1971, hlm. 276. Ibid.

80 Laporan Tahunan Lembaga Perancang Keluarga Negara 1973, National Family Planning Board Malaysia, hlm. 16.

81 Lihat, Kesihatan dan Peranchang Keluarga, dalam Rancangan Malaysia Kedua 1971-1975, hlm. 276.

82 Faktor pertambahan bilangan pasangan, kekurangan lawatan dan nasihat oleh kakitangan program, kelewatan kemasukan Perkhidmatan Perancang Keluarga ke dalam perkhidmatan kesihatan KKM. Faktor-faktor ini sebagaimana yang dinyatakan dalam Laporan Tahunan Lembaga Perancang Keluarga Negara, 1973, hlm. 16. 